\title{
DETERMINATION OF THE FACTORS LIMITING COTTON FIBER QUALITY IN TURKEY
}

\author{
Seyhan YASAR ${ }^{1, *}$, Emine KARADEMIR ${ }^{2}$ \\ *E-mail: seyhan.yasar@tarimorman.gov.tr
}

Received: Mar. 16, 2021. Revised: May 16, 2021. Accepted: May 20, 2021. Published online: May 24, 2021

\begin{abstract}
This study aims to determine the variation of fiber quality in cotton varieties produced in the Southeastern Anatolia Region and Şanlıurfa, Diyarbakir provinces. 1090 fiber samples were obtained from six cotton varieties (Lima, Stoneville 468, Candia and Babylon for Sanliurfa, Lima, Stoneville 468, Lodos and Gloria for Diyarbakir) collected from ginning factories in Şanlıurfa and Diyarbakir. Statistical analyzes were done with HVI device and obtained data were analyzed by using Excel and TOTEMSTAT programs. In the frequency distribution, cotton varieties of the region are in the medium and long fiber group in terms of fiber length. They were in the medium (only two samples), strong and very strong group in terms of fiber strength. They were generally in the medium and thick group in terms of fiber fineness (micronaire). In terms of fiber uniformity index, the majority of the fibers were in the middle group. In terms of short fiber index, most of the fibers were in the very low and low groups. The majority of the samples were in the high and medium
\end{abstract}

group in terms of fiber elongation, in the mature and very mature group in terms of fiber maturity. In terms of spinning consistency index (SCI) $59,2 \%$ of the fibers were between 119,41 and 135,83 ; $31,3 \%$ of them were between 135,83 and $152,24,58,2 \%$ of the material has a reflectance value of 74 and above. All materials were in white and light-yellow groups in terms of yellowness. It has been observed that the majority of the fibers $(66 \%)$ are in the low group in terms of trash count. The results obtained from the study of cotton produce of Southeastern Anatolia Region of Turkey has shown that good fiber quality and to meet the demand of textile industry.

Keywords: analysis; cotton; fiber; quality; variation.

\section{INTRODUCTION}

Cotton is an economically important product with its wide and compulsory usage area for humanity and the added value and labor force for the producer countries, biodiesel

\footnotetext{
1 GAP International Agricultural Research and Training Center, Diyarbakır, Turkey

${ }^{2}$ Siirt University, Faculty of Agriculture, Department of Field Crops, Siirt, Turkey
} 


\section{Seyhan YASAR, Emine KARADEMIR}

industry as oil produced from cotton seed (Anonymous, 2019a).

The softness of cotton products, good dyeing properties, high tensile strength, machine washable and no harm to human health make cotton fiber the natural fiber with the widest usage area (Öztürk, 2011).

Cotton belonging to the Gossypium hirsutum L. (Upland) type, which constitutes more than $80 \%$ of the cotton produced in the world and $99.5 \%$ of the cotton of our country. It is of American origin and has spread to many parts of the world due to its good adaptation ability. These kinds of cotton can be used in the production of not very fine yarn and fabric. In this type of cotton, yield and gin efficiency is high, vegetation period is medium-long (Gürel et al., 2000).

Cotton cultivation is done in Southeast Anatolia, Aegean, Antalya and Çukurova regions in Turkey. In 2019, cotton cultivation was carried out in these regions on a total area of 477,868 ha, and a total of $2,200,000$ tons of seed cotton with a yield of $4600 \mathrm{~kg}$ per hectare was obtained from these areas. In the Southeastern Anatolia Region, where $60 \%$ of our country's cotton production is provided, cotton cultivation was carried out in 288,914 ha and $1,312,703$ tons of seed cotton was obtained from these areas with a yield of $4540 \mathrm{~kg}$ per hectare. The most cotton production in this region is made in Diyarbakir and Şanlıurfa provinces. In Şanlıurfa, $37 \%$ of our country's cotton production is met by obtaining 813,258 tons of cotton with a yield of $3900 \mathrm{~kg}$ per hectare from cotton farming in an area of 208,792 ha. In Diyarbakir, $10 \%$ of our country's cotton production was met by producing 233,707 tons of seed cotton with a yield of $4900 \mathrm{~kg}$ per hectare on an area of 476,866 ha (Anonymous, 2019b).

Technological advances in the textile sector, the increase in consumption demand with the population increase, the prominence of fiber quality parameters, high raw material costs increase the demand for domestic and high-quality cotton. It is necessary to determine the quality criteria of cotton, which is increasingly important, with methods suitable for today's technology, and to ensure the standardization of cotton, thus creating a common language with other countries in the world (Sabır and Güzel, 2010). The cotton fiber quality not only depends on seed genetics, environmental conditions, but also on the type of ginning system and drying techniques employed (Siddiqui et al., 2020).

When the researches about quality are examined the varieties are different in terms of many quality features and that even when the same variety is planted in different locations, there are differences in quality characteristics. It has been reported that these differences are caused by the genotypic characteristics of the cultivated cultivars in some cases and environmental factors in some cases, but mostly due to the interaction of both factors (Özbek et al., 2014). 


\section{DETERMINATION OF THE FACTORS LIMITING COTTON FIBER QUALITY}

Classification of cotton in Turkey is based on "Communiqué on the Standardization of Cotton" published in 2012 and cotton types are classified as Turkey, Turkey-Aegean, Turkey Aegean type, TurkeyÇukurova. Southeastern Anatolia cotton enters the Turkey-Aegean Type. There is no additional standardization for the cotton of the region. With this study, a resource will be created for the standardization of regional cotton.

This study aims to examine the limits of change in cotton fiber quality criteria in the Southeastern Anatolia Region and the provinces of Şanlıurfa and Diyarbakir, where cotton production is the most important in this region, to reveal the fiber quality criteria both on the basis of the region and the province, and also carried out in order to determine the quality characteristics of cotton varieties widely cultivated in the region.

\section{MATERIALS AND METHODS}

\section{Animals and study design}

In the study, 1090 fiber samples were collected from the ginning factories in Şanlıurfa and Diyarbakir within the scope of the EU/IPA Project "Regional Industrial Cooperation in Cotton Fiber Production" carried out by the GAP International Agricultural Research and Training Center (GAPUTAEM). Fiber samples obtained from mechanized harvesting in October-November 2018 were used. As material in the study Lima and Stoneville 468 varieties grown jointly in Şanlıurfa and Diyarbakir provinces; Candia and Babylon varieties are grown in Şanlıurfa, Lodos and Gloria varieties grown in Diyarbakir were used as shown below (Table 1). Among these varieties, Gloria and Lodos varieties grown in Diyarbakir were ginned with a saw-gin machine and other varieties with a rollergin machine. Fiber quality analyzes were carried out in the GAP Cotton Fiber Test and Analysis Laboratory established within GAPUTAEM, by using the High Volume Instrument (HVI) device after performing the necessary conditions.

Climate data of Diyarbakir province where the study was conducted are given in Table 2, and climate data of Şanliurfa province are given in Table 3. When both charts are examined, it is seen that the average temperature and average maximum temperature values of 2018, when the study was conducted, were realized slightly above the average temperature values for long years. It was observed that the amount of precipitation in May, which is the planting period of 2018, was much higher than the average of long years, the amount of rainfall in September and October, which is the harvest period, was above long years in Diyarbakir, but it was lower in September and higher in October in Şanlıurfa.

About 150-200 grams ginned cotton fiber samples were taken from the ginning factories in Diyarbakir and Şanlıurfa, brought to the GAP Cotton Fiber Test and Analysis Laboratory and province, variety name, moisture level, ginning methods and date were recorded in the computer.

Since fiber analysis is affected by many factors, reliable results have been obtained with the quality control procedures in the laboratory. Proper calibration of the HVI device ensures consistency and accuracy of the laboratory (Anonymous, 2014). According to ASTM D-1776 Standard, $21 \pm 1^{\circ} \mathrm{C}$ temperature and $65 \pm 2 \%$ relative humidity values were provided in the laboratory and according to ASTM D-5867 standard, 


\section{Seyhan YASAR, Emine KARADEMIR}

the humidity of the analyzed samples was adjusted to be between $6.75-8.25 \%$. For this, samples were kept under laboratory conditions for 24-48 hours, in other words, passively conditioned and taken for analysis.

Table 1 - The cotton varieties used in the experiment, their number and the places of cultivation

\begin{tabular}{lll}
\hline Variety & Number & Place of cultivation \\
\hline LIMA & $25+25$ & Diyarbakir, Şanlıurfa \\
\hline STONEVILLE 468 & $200+200$ & Diyarbakir, Şanlıurfa \\
\hline LODOS & 200 & Diyarbakir \\
\hline GLORIA & 200 & Diyarbakir \\
\hline CANDIA & 200 & Şanlıurfa \\
\hline BABYLON & 40 & Şanlıurfa \\
\hline
\end{tabular}

Table 2 - Climate data of Diyarbakir for 2018 and long years

\begin{tabular}{|c|c|c|c|c|c|c|c|c|}
\hline \multirow[t]{2}{*}{ Months } & \multicolumn{2}{|c|}{$\begin{array}{c}\text { Average } \\
\text { temperature } \\
\left({ }^{\circ} \mathrm{C}\right)\end{array}$} & \multicolumn{2}{|c|}{$\begin{array}{c}\text { Average } \\
\text { maximum } \\
\text { temperature } \\
\left({ }^{\circ} \mathrm{C}\right)\end{array}$} & \multicolumn{2}{|c|}{$\begin{array}{l}\text { Precipitation } \\
(\mathrm{mm})\end{array}$} & \multicolumn{2}{|c|}{$\begin{array}{c}\text { Average } \\
\text { relative } \\
\text { humidity (\%) }\end{array}$} \\
\hline & 2018 & $\begin{array}{l}\text { Long } \\
\text { years }\end{array}$ & 2018 & $\begin{array}{l}\text { Long } \\
\text { years }\end{array}$ & 2018 & $\begin{array}{l}\text { Long } \\
\text { years }\end{array}$ & 2018 & $\begin{array}{l}\text { Long } \\
\text { years }\end{array}$ \\
\hline April & 15.9 & 13.8 & 24.0 & 20.2 & 48.6 & 68.7 & 52.9 & 63 \\
\hline May & 19.4 & 19.3 & 26.5 & 26.5 & 157.6 & 42.8 & 67.3 & 56 \\
\hline June & 26.6 & 26.3 & 34.5 & 33.7 & 14.4 & 8.0 & 37.4 & 31 \\
\hline July & 31.2 & 31.2 & 39.3 & 38.4 & 0 & 0.7 & 24.1 & 27 \\
\hline August & 31.4 & 30.3 & 39.1 & 38.1 & 0.8 & 0.4 & 24.1 & 28 \\
\hline September & 26.1 & 24.8 & 34.6 & 33.2 & 6.2 & 3.9 & 29.3 & 32 \\
\hline October & 18.7 & 17.2 & 25.8 & 25.2 & 76.6 & 31.7 & 52.3 & 48 \\
\hline
\end{tabular}

Table 3 - Climate data of Şanlıurfa for 2018 and long years

\begin{tabular}{lcccccccc}
\hline Months & \multicolumn{2}{c}{$\begin{array}{c}\text { Average } \\
\text { temperature }\left({ }^{\circ} \mathbf{C}\right)\end{array}$} & \multicolumn{2}{c}{$\begin{array}{c}\text { Average } \\
\text { maximum } \\
\text { temperature }\left({ }^{\circ} \mathbf{C}\right)\end{array}$} & \multicolumn{2}{c}{$\begin{array}{c}\text { Precipitation } \\
(\mathbf{m m})\end{array}$} & \multicolumn{2}{c}{$\begin{array}{c}\text { Average } \\
\text { relative } \\
\text { humidity (\%) }\end{array}$} \\
\hline April & $\mathbf{2 0 1 8}$ & $\begin{array}{c}\text { Long } \\
\text { years }\end{array}$ & $\mathbf{2 0 1 8}$ & $\begin{array}{l}\text { Long } \\
\text { years }\end{array}$ & $\mathbf{2 0 1 8}$ & $\begin{array}{l}\text { Long } \\
\text { years }\end{array}$ & $\mathbf{2 0 1 8}$ & $\begin{array}{c}\text { Long } \\
\text { years }\end{array}$ \\
\hline May & 19.9 & 16.1 & 27.0 & 22.3 & 35.8 & 49.4 & 38.4 & 55.11 \\
\hline June & 23.0 & 22.1 & 29.8 & 28.6 & 64.5 & 26.1 & 50.1 & 45.00 \\
\hline July & 28.6 & 28.1 & 36.2 & 34.6 & 10.1 & 3.5 & 36.6 & 34.44 \\
\hline August & 31.9 & 31.9 & 39.3 & 38.7 & 0 & 0.6 & 34.2 & 31.86 \\
\hline September & 32.2 & 31.3 & 39.2 & 38.3 & 0 & 0.6 & 33.6 & 37.49 \\
\hline October & 28.8 & 26.8 & 35.9 & 33.9 & 2.2 & 2.5 & 31.3 & 40.55 \\
\hline & 21.6 & 20.2 & 27.7 & 27.0 & 39.4 & 24.6 & 45.6 & 48.37 \\
\hline
\end{tabular}

\section{RESULTS AND DISCUSSION}

In the study fiber quality properties of 1090 fiber samples were evaluated using HVI analysis and obtained results are given as tables (Tables 4 - 9).

Fiber length $(\mathbf{m m})$. When the samples collected from the Southeastern Anatolia Region are 
evaluated in terms of fiber length values, it has been determined that the fiber lengths vary between $27.76 \mathrm{~mm}$ (from Stoneville 468 variety cultivated in Şanlıurfa) and $31.58 \mathrm{~mm}$ (from Candia variety cultivated in Şanlıurfa) as shown Table 4. When Lima and Stoneville 468 varieties cultivated jointly in Şanlıurfa and
Diyarbakir were evaluated together, it was determined that the best result was obtained from Diyarbakir with $31.28 \mathrm{~mm}$ in Lima variety, and in Şanlıurfa with $30.91 \mathrm{~mm}$ in Stoneville 468 variety. It has been determined that Southeastern Anatolia, Şanlıurfa and Diyarbakir cottons all enter into the medium and long fiber class.

Table 4 - Values of Variation Limits in Fiber Length and Fiber Fineness

\begin{tabular}{lcccccccccc}
\hline Traits & \multicolumn{4}{c}{ Fiber length (mm) } & \multicolumn{4}{c}{ Fiber fineness (micronaire) } \\
\cline { 2 - 11 } & Min. & Max. & Mean & Var. & SD & Min. & Max. & Mean & Var. & SD \\
\hline $\begin{array}{l}\text { Babylon } \\
\text { (Şanlıurfa) }\end{array}$ & 28.20 & 31.34 & 29.14 & 0.37 & 0.61 & 4.52 & 5.05 & 4.77 & 0.02 & 0.13 \\
\hline $\begin{array}{l}\text { Candia } \\
\text { (Şanlıurfa) }\end{array}$ & 28.00 & 31.58 & 29.43 & 0.61 & 0.78 & 4.36 & 5.20 & 4.78 & 0.03 & 0.18 \\
\hline $\begin{array}{l}\text { Lima } \\
\text { (Şanlıurfa) }\end{array}$ & 28.84 & 30.89 & 29.78 & 0.23 & 0.48 & 4.35 & 4.79 & 4.55 & 0.01 & 0.11 \\
\hline $\begin{array}{l}\text { Stoneville } \\
\text { 468 } \\
\text { (Şanlıurfa) }\end{array}$ & 27.76 & 30.91 & 28.85 & 0.34 & 0.59 & 4.00 & 5.60 & 4.85 & 0.09 & 0.30 \\
\hline $\begin{array}{l}\text { Gloria } \\
\text { (Diyarbakır) }\end{array}$ & 28.00 & 30.01 & 28.49 & 0.15 & 0.39 & 3.79 & 4.65 & 4.29 & 0.03 & 0.17 \\
\hline $\begin{array}{l}\text { Lodos } \\
\text { (Diyarbakır) }\end{array}$ & 27.86 & 31.04 & 28.69 & 0.23 & 0.48 & 4.08 & 4.54 & 4.32 & 0.01 & 0.08 \\
\hline $\begin{array}{l}\text { Lima } \\
\text { (Diyarbakır) }\end{array}$ & 29.03 & 31.28 & 30.08 & 0.32 & 0.56 & 4.21 & 4.76 & 4.44 & 0.02 & 0.14 \\
\hline $\begin{array}{l}\text { Stoneville } \\
\begin{array}{l}668 \\
\text { (Diyarbakır) }\end{array}\end{array}$ & 27.78 & 30.50 & 28.92 & 0.30 & 0.55 & 4.03 & 5.17 & 4.55 & 0.05 & 0.21 \\
\hline $\begin{array}{l}\text { Sanlıurfa } \\
\text { Diyarbakır }\end{array}$ & 27.76 & 31.58 & 29.17 & 0.54 & 0.74 & 4.00 & 5.60 & 4.80 & 0.06 & 0.24 \\
\hline $\begin{array}{l}\text { Southeastern } \\
\text { Anatolia } \\
\text { Region }\end{array}$ & 27.76 & 31.28 & 28.76 & 0.33 & 0.58 & 3.79 & 5.17 & 4.39 & 0.04 & 0.20 \\
\hline
\end{tabular}

They reported that fiber length is the most important fiber quality criterion, for the textile industry demands long and strong fibers to produce high-quality fabrics and this determines the price of the product (Long et al., 2010). The findings are in line with Özbek (2013) study, where the fiber length of the country's cotton varieties are ranged from 26 to
$32.5 \mathrm{~mm}$, with an average $29.1 \mathrm{~mm}$ which are good value in terms of fiber length. Fiber length is affected by genetics as well as maintenance and environmental conditions. It is reported that $80.6 \%$ environment and $5.1 \%$ genotype are the determining factors in the management of fiber length (Snider et al., 2013). It has been reported that fiber length is 


\section{Seyhan YASAR, Emine KARADEMIR}

negatively affected by moisture content, irrigation frequency-amount and temperature changes in the soil. Good management of plant water relations at the stage of fiber growth also affects this feature and fiber length is also affected by the ginning method (Reddy et al., 1999; Silvertooth, 2001; Van der Suijs, 2015).

Fiber fineness (micronaire). When the varieties were examined in terms of micronaire, Gloria variety cultivated in Diyarbakir got the lowest value (medium) with 3.79 micronaire, and Stoneville 468 cultivated in Şanliurfa got the highest value (very coarse) with 5.60 micronaire (Table 4). When Lima and Stoneville 468, which are common varieties planted in Şanlıurfa and Diyarbakir, are evaluated together, Lima variety is in the medium group in Diyarbakir with values between 4.21 and 4.76, Stoneville 468 variety in Şanlıurfa with values reaching 5.60 it was determined to be in the coarse and even very coarse group. It has been observed that approximately $77 \%$ of the fiber samples (834 samples) in the Southeastern Anatolia Region are in the medium group, $23 \%$ (255 samples) in the coarse group and only one sample is in the very coarse group.

Although micronaire is a hereditary feature, the climatic conditions during the growing period of the plant are affected by humidity, temperature, sunlight, plant nutrients and sowing frequency. Green and Culp (1990) reported that the environmental impact on micronaire was insignificant, while Snider et al.
(2013) reported that $63.8 \%$ environment and $9.9 \%$ of genotype are effective in the management of micronaire.

Fiber strength $\left(\mathrm{g} \mathrm{tex}^{-1}\right)$. When the varieties were evaluated in terms of fiber strength, it was determined that the fiber strength ranged between $26.90 \mathrm{~g} \mathrm{tex}^{-1}$ (in Lodos variety cultivated in Diyarbakir) and $36.37 \mathrm{~g}$ tex $^{-1}$ (seen in Babylon variety cultivated in Şanliurfa). When Lima and Stoneville 468 varieties cultivated jointly in Şanlıurfa and Diyarbakir were evaluated together, it was determined that Lima variety obtained the highest value in terms of fiber strength with $36.12 \mathrm{~g} \mathrm{tex}^{-1}$ and Stoneville 468 with $36.28 \mathrm{~g}$ tex $^{-1}$ in Şanliurfa (Table 5). Approximately $51 \%$ (560 samples) of fiber samples in the Southeastern Anatolia Region are in the strong group, 49\% (528 samples) are in the very strong group and only 2 are in the medium group.

The higher values obtained in Şanllurfa may be due to differences in climate and maintenance conditions. It is reported that there is a positive and significant correlation between the daily average temperature and fiber strength during fiber formation (Wang et al., 2009; Wang et al., 2014). When the climate data are examined, it is seen that the average temperature and maximum temperature values in Şanlıurfa are higher than in Diyarbakir. 


\section{DETERMINATION OF THE FACTORS LIMITING COTTON FIBER QUALITY}

Table 5 - Values of Variation Limits in Fiber Strength and Fiber Elongation

\begin{tabular}{|c|c|c|c|c|c|c|c|c|c|c|}
\hline \multirow{2}{*}{ Traits } & \multicolumn{5}{|c|}{ Fiber strength $\left(g\right.$ tex $\left.{ }^{-1}\right)$} & \multicolumn{5}{|c|}{ Fiber elongation (\%) } \\
\hline & Min. & Max. & Mean & Var. & SD & Min. & Max. & Mean & Var. & SD \\
\hline $\begin{array}{l}\text { Babylon } \\
\text { (Şanlıurfa) }\end{array}$ & 28.94 & 36.37 & 32.34 & 2.55 & 1.60 & 5.52 & 6.61 & 5.86 & 0.04 & 0.20 \\
\hline $\begin{array}{l}\text { Candia } \\
\text { (Şanlıurfa) }\end{array}$ & 28.97 & 35.25 & 31.71 & 1.86 & 1.36 & 5.43 & 6.86 & 5.87 & 0.08 & 0.28 \\
\hline $\begin{array}{l}\text { Lima } \\
\text { (Şanlıurfa) }\end{array}$ & 30.26 & 36.12 & 31.92 & 2.37 & 1.54 & 6.04 & 7.18 & 6.60 & 0.07 & 0.26 \\
\hline $\begin{array}{l}\text { Stoneville } \\
468 \\
\text { (Şanlıurfa) }\end{array}$ & 28.17 & 36.28 & 31.33 & 2.21 & 1.49 & 5.15 & 7.72 & 6.23 & 0.42 & 0.65 \\
\hline $\begin{array}{l}\text { Gloria } \\
\text { (Diyarbakır) }\end{array}$ & 28.97 & 34.82 & 31.17 & 1.28 & 1.13 & 6.10 & 7.57 & 6.84 & 0.08 & 0.28 \\
\hline $\begin{array}{l}\text { Lodos } \\
\text { (Diyarbakır) }\end{array}$ & 26.90 & 31.98 & 29.98 & 0.83 & 0.91 & 6.58 & 7.72 & 7.01 & 0.04 & 0.19 \\
\hline $\begin{array}{l}\text { Lima } \\
\text { (Diyarbakır) }\end{array}$ & 30.72 & 33.97 & 32.23 & 0.70 & 0.84 & 6.30 & 7.09 & 6.64 & 0.04 & 0.20 \\
\hline $\begin{array}{l}\text { Stoneville } \\
468 \\
\text { (Diyarbakır) }\end{array}$ & 27.98 & 35.51 & 30.87 & 1.78 & 1.34 & 5.76 & 8.14 & 6.79 & 0.28 & 0.52 \\
\hline Şanlıurfa & 8.17 & 36.37 & 31.61 & 2.17 & 1.47 & 5.15 & 7.72 & 6.06 & 0.27 & 0.52 \\
\hline Diyarbakır & 26.90 & 35.51 & 30.74 & 1.61 & 1.27 & 5.76 & 8.14 & 6.87 & 0.14 & 0.37 \\
\hline $\begin{array}{l}\text { Southeastern } \\
\text { Anatolia } \\
\text { Region }\end{array}$ & 26.90 & 36.37 & 31.11 & 2.03 & 1.43 & 5.15 & 8.14 & 6.53 & 0.35 & 0.59 \\
\hline
\end{tabular}

Fiber elongation (\%). When the varieties were evaluated in terms of fiber elongation, it was determined that the highest value was obtained from Stoneville 468 cultivated in Diyarbakir with $8.14 \%$, and the lowest value was obtained from Stoneville 468 cultivated in Şanliurfa with $5.15 \%$ (Table 5). When Lima and Stoneville 468 were evaluated together, it was seen that the highest fiber elongation value was obtained from Lima variety in Şanliurfa with $7.18 \%$ and Stoneville 468 in Diyarbakir with $8.14 \%$. About $40 \%$ (43 samples) of the fiber samples analyzed in the region are in the high group in terms of fiber elongation, $38 \%$ (414 samples) in the medium group, $22 \%$ (238 samples) in the low group and only 6 samples in the very high group.

Fiber elongation has an important role in textile production processes, and high fiber elongation allows fibers to be processed without breaking (Kelly etal., 2019; Mathangadeera etal., 2020). The high number of fiber samples with low fiber elongation in Şanliurfa may be due to genotype, year and genotype $\mathrm{x}$ year interaction. Karademir et al. (2015) reported that genotype $\mathrm{x}$ year interaction was significant in fiber elongation which reflect fiber elongation of genotypes can be changed depend on years. Quisenberry and Kohel (1975) revealed that environment influenced the rate of fiber elongation. 


\section{Seyhan YASAR, Emine KARADEMIR}

Fiber uniformity (\%). It's seen that from the Table 6 when the varieties were evaluated in terms of fiber uniformity index, the best value was obtained from Candia variety planted in Şanliurfa with $87.32 \%$, and the lowest value was obtained from Gloria variety planted in Diyarbakir with $76.16 \%$. When Lima and Stoneville 468 were evaluated together, it was seen that the Lima variety showed the best value with $86.69 \%$ and Stoneville 468 with $86.65 \%$ in Şanlıurfa. Approximately $82 \%$ (899 sample) of the fiber samples analyzed in the Southeastern Anatolia Region were in the medium group in terms of fiber uniformity index, $13 \%$ in the low group, $4 \%$ (43 samples) in the high group and one in the very low and very high group.

Studies have reported that the environment contributes $69.8 \%$ and genotype contributes $6.5 \%$ to the management of fiber uniformity index (Snider et al., 2013). The fact that all types are ginned with roller-gin in Şanliurfa and achieving better uniformity index support Van der Suijs' (2015) determination that ginning methods are important in terms of this feature and the fibers ginned with roller-gin are more uniform.

Fiber maturity (\%). When the varieties were evaluated in terms of maturity index, it was seen that Stoneville 468 variety cultivated in Diyarbakir had the highest value with a ratio of 1, and Stoneville 468 cultivated in Şanliurfa had the lowest value with 0.84 (Table 6).
When Lima and Stoneville 468 were evaluated together, it was determined that Lima variety received the best value in Şanliurfa with 0.97 , and Stoneville 468 variety received the best value in Diyarbakir with 1. It was determined that approximately $84 \%$ of the fiber samples (915 samples) analyzed in the Southeastern Anatolia Region were in the mature group, $8 \%$ (88 samples) were very mature, and the remaining $8 \%$ ( 87 samples) were in the immature group.

The values obtained in terms of maturity index show no maturity problem in the cotton varieties cultivated in the region. However, the fact that there are fiber samples in the immature group $(13 \%)$ in Diyarbakir supports Braden et al. (2004) and Özbek et al. (2014) determination that saw-gin ginning decreases maturity index. The maturity index can vary depending on the variety, planting time, product management system, climatic conditions and harvest time. Elms et al. (2001) reported that micronaire is low in immature cotton fibers.

Short fiber index (\%). When the cotton planted in the Southeastern Anatolia Region is evaluated in terms of short fiber index, the Lima variety cultivated in Şanliurfa has the lowest value with $4.56 \%$ and Gloria cultivated in Diyarbakir has the highest value with $15.92 \%$ (Table 7 ). When Lima and Stoneville 468 were evaluated together, it was seen that Lima variety received $4.56 \%$ and Stoneville 468 variety received the best value in Şanllurfa with $5.00 \%$. 


\section{DETERMINATION OF THE FACTORS LIMITING COTTON FIBER QUALITY}

Approximately $76 \%$ of the fiber samples analyzed in the Southeastern Anatolia Region (823 samples) in terms of short fiber index were in the low group, $18 \%$ (197 samples) in the medium group, 6\% (68 samples) in the very low group and only two fibers example is in the high group. Studies conducted show that the short fiber index is also affected by harvest, ginning, and product processing methods (Bradow and Davidonis, 2000). Short fiber ratio is a feature associated with immature fiber content and negatively affects the process of spinning (Manandhar, 2013).

Table 6 - Values of Variation Limits in Fiber Uniformity and Fiber Maturity

\begin{tabular}{lcccccccccc}
\hline \multirow{2}{*}{ Traits } & \multicolumn{4}{c}{ Fiber uniformity (\%) } & \multicolumn{5}{c}{ Fiber maturity (\%) } \\
\cline { 2 - 10 } & Min. & Max. & Mean & Var. & SD & Min. & Max. & Mean & Var. & SD \\
\hline $\begin{array}{l}\text { Babylon } \\
\text { (Şanlıurfa) }\end{array}$ & 81.16 & 85.26 & 83.03 & 0.80 & 0.89 & 0.90 & 0.99 & 0.95 & 0.00 & 0.02 \\
\hline $\begin{array}{l}\text { Candia } \\
\text { (Şanlıurfa) }\end{array}$ & 79.79 & 87.32 & 83.38 & 1.33 & 1.15 & 0.87 & 0.99 & 0.90 & 0.00 & 0.03 \\
\hline $\begin{array}{l}\text { Lima } \\
\text { (Şanlıurfa) }\end{array}$ & 81.98 & 86.69 & 83.60 & 1.16 & 1.07 & 0.88 & 0.97 & 0.93 & 0.00 & 0.02 \\
\hline $\begin{array}{l}\text { Stoneville } \\
\text { 468 } \\
\text { (Şanlıurfa) }\end{array}$ & 81.15 & 86.65 & 83.77 & 0.85 & 0.92 & 0.84 & 0.97 & 0.88 & 0.00 & 0.02 \\
\hline $\begin{array}{l}\text { Gloria } \\
\text { (Diyarbakır) }\end{array}$ & 76.16 & 83.99 & 81.34 & 1.48 & 1.22 & 0.85 & 0.89 & 0.86 & 0.00 & 0.01 \\
\hline $\begin{array}{l}\text { Lodos } \\
\text { (Diyarbakır) }\end{array}$ & 77.41 & 83.91 & 81.31 & 0.88 & 0.94 & 0.85 & 0.87 & 0.86 & 0.00 & 0.00 \\
\hline $\begin{array}{l}\text { Lima } \\
\text { (Diyarbakır) }\end{array}$ & 80.37 & 85.60 & 82.97 & 1.48 & 1.22 & 0.89 & 0.96 & 0.92 & 0.00 & 0.02 \\
\hline $\begin{array}{l}\text { Stoneville } \\
\text { 468 }\end{array}$ & 80.49 & 86.43 & 83.44 & 0.88 & 0.94 & 0.85 & 1.00 & 0.91 & 0.00 & 0.03 \\
\hline (Diyarbakır) & 79.79 & 87.32 & 83.53 & 1.12 & 1.06 & 0.84 & 0.99 & 0.90 & 0.00 & 0.03 \\
\hline $\begin{array}{l}\text { Şanlıurfa } \\
\text { Diyarbakır }\end{array}$ & 76.16 & 86.43 & 82.07 & 2.08 & 1.44 & 0.85 & 1.00 & 0.88 & 0.00 & 0.03 \\
\hline $\begin{array}{l}\text { Southeastern } \\
\text { Anatolia } \\
\text { Region }\end{array}$ & 76.16 & 87.32 & 82.69 & 2.19 & 1.48 & 0.84 & 1.00 & 0.89 & 0.00 & 0.03 \\
\hline
\end{tabular}

Spinning consistency index (SCI). When the varieties are evaluated in terms of spinning consistency index, it is seen that the highest value is obtained from the Lima variety cultivated in Şanliurfa with 168.65 , and the lowest value is from Gloria variety cultivated in Diyarbakir with 103.00 as shown in Table 7. When Lima and Stoneville
468 were evaluated together, it was determined that the Lima variety got 168.65 and Stoneville 468 got 162.85 the best results in Şanlıurfa. Only 5\% of Diyarbakir, approximately $1 \%$ of Şanlıurfa and approximately $3 \%$ of the Southeastern Anatolia Region cotton have a value lower than 115 . 


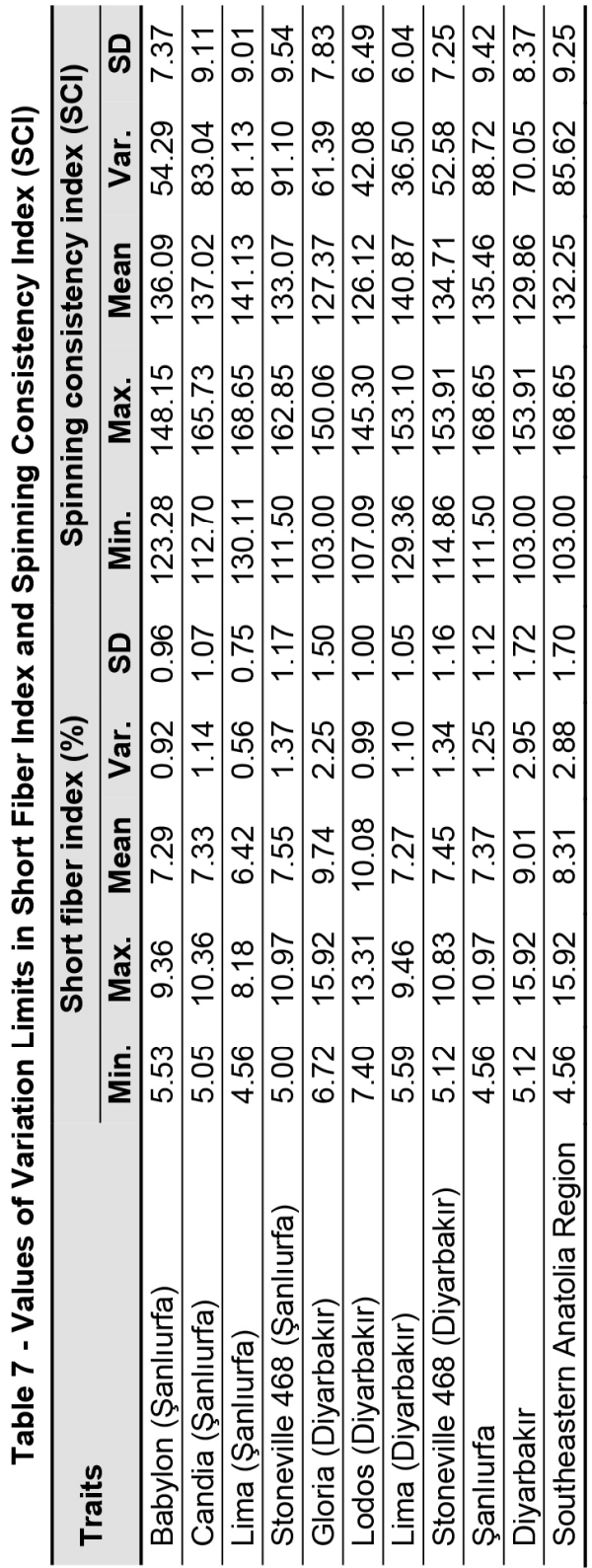

The spinning consistency index in cotton is a feature that includes important fiber quality properties and is determined with the help of the regression equation and reflects the

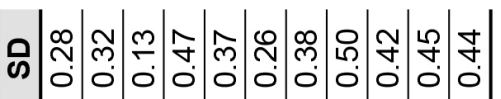

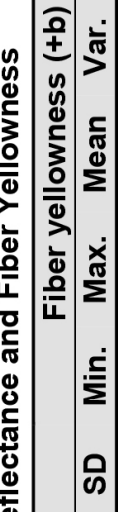

:

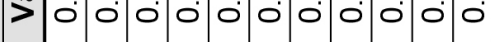

ᄃํㅔ

$\begin{array}{lllllllllllllllllllll} & \infty & \infty & \infty & \infty & \infty & \infty & \infty & \infty & \infty & \infty & \infty\end{array}$

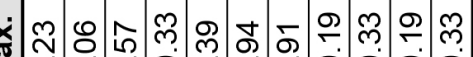

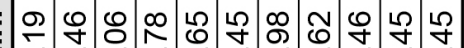

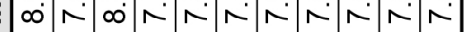

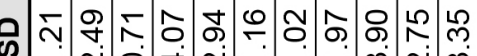
$\sim$ No

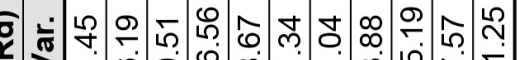

is

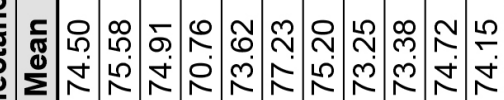

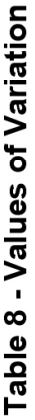

$\times$ 잉으잉

。

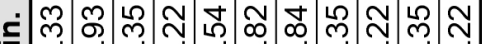

ए

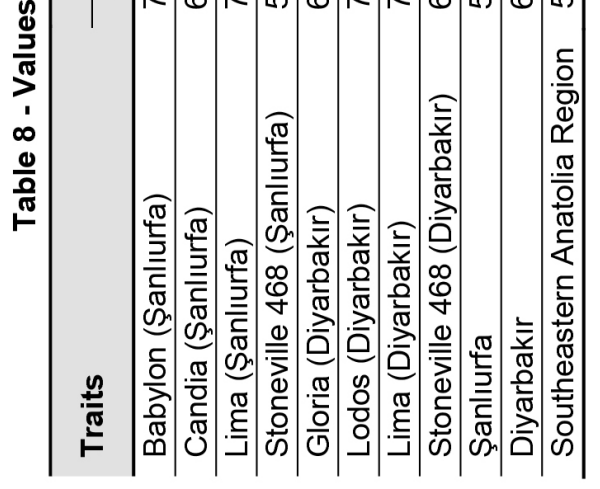

quality of the yarn. The formula includes micronaire, strength, length, uniformity and color values. A high SCI value is a desired feature, the higher this value means, the better 


\section{DETERMINATION OF THE FACTORS LIMITING COTTON FIBER QUALITY}

yarn quality. The SCI value varies between 100 and 150, this value increases up to 200 in long-fiber cotton. Majumdar et al. (2005) reported in their study that they achieved SCI values ranging from 101.7 to 155.6 .

Fiber reflectance (Rd). When the varieties were evaluated in terms of fiber reflectance (Rd), it was determined that the best value was obtained from the Candia variety cultivated in Şanliurfa with 79.10, and the lowest value was obtained from Stoneville 468 cultivated in Şanlıurfa with 59.22 (Table 8). When Lima and Stoneville 468, which are the common varieties planted in Şanliurfa and Diyarbakir, were evaluated together, it was determined that the Lima variety got the best values with 76.82 and Stoneville 468 with 76.94 in Diyarbakir. Approximately $89 \%$ of the fiber samples analyzed in the Southeastern Anatolia Region were in the bright (967 samples) group, 9\% (98 samples) in the medium bright group and the remaining $2 \%$ (25 sample) in the matte group.

In the frequency distribution made in terms of fiber reflectance (Rd) in the Southeastern Anatolia Region, it is seen that $58.2 \%$ of the material has a fiber reflectance (Rd) value of 74 and above. This indicates that there is no fiber reflectance (Rd) problem in the area. The findings are in line with Özbek (2013) study, where the fiber reflectance (Rd) of the country's cotton varies between 56-82, and the average is 70 .

Fiber yellowness $(+\mathbf{b})$. When the varieties were evaluated in terms of fiber yellowness $(+b)$, the best value was Lodos cultivated in Diyarbakir with 7.45 , while the worst value was Stoneville 468 cultivated in Şanlıurfa with 10.33 (Table 8). When Lima and Stoneville 468, were evaluated together, it was determined that Lima variety got the best value with 7.98 and Stoneville 468 with 7.62 in Diyarbakir. It has been determined that approximately $91 \%$ of the fiber samples (994 samples) in the Southeastern Anatolia Region are in the light-yellow group and the remaining 9\% (96 samples) are in the white group.

Exposure of the bolls that opened during the harvest period to rain causes an increase in the yellowness (+b) of the fibers. Meredith (1986) reported that $79 \%$ of the variation in color change is caused by environmental factors.

Trash count. When the varieties were evaluated in terms of the trash count, it was determined that Candia variety cultivated in Şanliurfa got the best value with 12, and Stoneville 468 cultivated in Diyarbakir got the worst value with 233 (Table 9). When Lima and ST 468 were evaluated together, it was determined that Lima variety got the best value with 50 and Stoneville 468 with 27 in Şanlıurfa. In terms of trash count of the cotton varieties analyzed in the Southeastern Anatolia Region, 66\% (719 samples) are in the low group, $17 \%$ (187 samples) are in the medium group, 9\% (97 samples) are in the high group, about 6\% (64 samples) were found to be in the very low group and $2 \%$ (23 samples) in the very high group. 


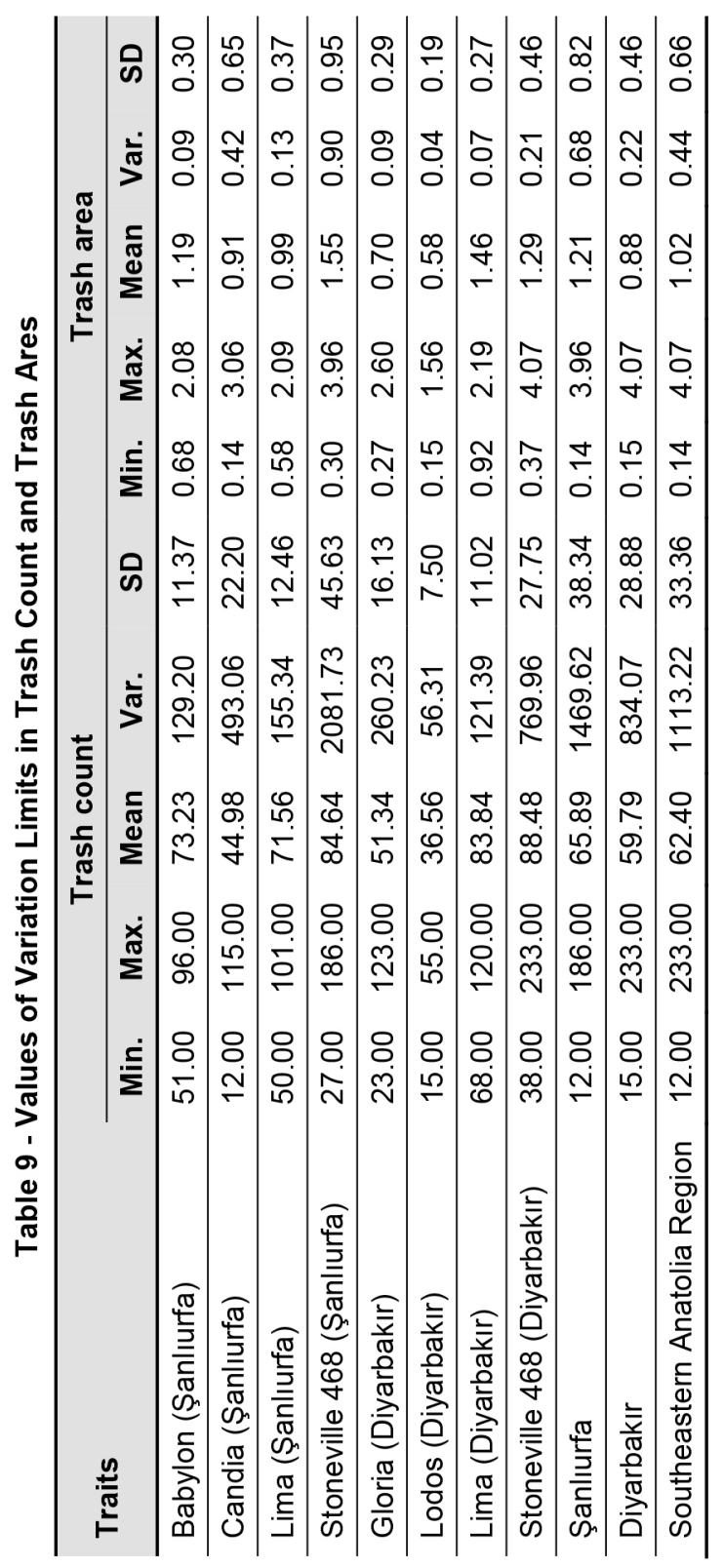

Özbek (2013) reports that the number of trash count of cotton produced in our country varies between 0 and 190, in this respect, the study was paralleled (a single sample exceeded 190 by taking 233 values). In addition, because the varieties planted in Diyarbakir (Lodos and Gloria) were ginned with saw-gin, they were cleaner in terms of trash 
count. Our findings confirm the studies of Tümer (2010), Özbek et al. (2014) and Van der Suijs (2015) on ginning methods.

Trash area. When the varieties were evaluated in terms of trash area, as shown in Table 9, it was determined that the best value was Candia cultivated in Şanliurfa with $0.14 \%$ and the worst value was Stoneville 468 cultivated in Diyarbakir with $4.07 \%$. When Lima and Stoneville 468 were evaluated together, it was determined that the Lima variety got the best value with $0.58 \%$ and Stoneville 468 with $0.30 \%$ in Şanlıurfa. Approximately $67 \%$ (726 samples) of the 1090 fiber samples analyzed in the region were in the cleanest group, $33 \%$ (356 samples) in the clean group, only 7 of them were in the middle, and only one of them was in the dirty group.

\section{CONCLUSION}

In this study, 1090 fiber samples were examined to determine the fiber quality criteria of cotton varieties produced in the Southeastern Anatolia Region and the limits of change in cotton fibers in the region. The findings obtained were determined that the length, micronaire, fiber strength, short fiber index, maturity, reflectance $(\mathrm{Rd})$, yellowness $(+b)$, and spinning consistency index (SCI) were within the appropriate limits. However, it was determined that the trash count was slightly higher, and the fiber uniformity index and the elongation were low.
In order for the cotton of the region to be visible and reputable in national and international markets, it should be ensured that the ginningpress enterprises switch to a single bale system, the fiber quality values of each bale should be supported by HVI analyzes, and this information must be included in the label information. Thus, disputes in international trade will be minimized, and the cotton produced will market at the value it deserves.

To prevent the trash count in the region, harvesting and helping the harvesting practices should be done carefully and consciously. Care should be taken to adjust the harvesting machines. Attention should be paid to the harvest time; harvesting should be done after allowing the cotton exposed to rain to dry. Training on this subject should be organized and efforts to reduce trash count should be supported.

Machinery and equipment in the ginning-press factories should be modernized, and governmental incentives should be given to these companies. Since it is not possible to insurance cotton fiber in our region in cotton ginning factories, licensed warehousing should be opened in Diyarbakir and Şanlıurfa, because in licensed warehousing when the farmers deliver their cotton it is automatically became insured. Thus, every bale will be analyzed in laboratories accepted as authorized classifiers, stored under appropriate conditions, and offered for sale when prices rise. 


\section{Seyhan YASAR, Emine KARADEMIR}

\section{REFERENCES}

Anonymous (2019a). T.C. Ticaret Bakanlığı Esnaf, Sanatkârlar ve Kooperatifçilik Genel Müdürlüğü 2018 Yılı Pamuk Raporu, https://ticaret.gov.tr/data/5d41e5991 3b87639ac9e02e8/d0e2b9c7923468 4ad29baf256a0e7dce.pdf [Date of Visit: February 11, 2020].

Anonymous (2019b). Türkiye İstatistik Kurumu, https://biruni.tuik.gov.tr/ medas/?locale $=\operatorname{tr}$ [Date of Visit: February 11, 2020].

Anonymous (2014). Uster HVI 1000 Application Handbook, USTER Technologies AG, Switzerland, 2-1, 4-29, https://csitc.org/sitecontent/ RTCEA/internal_ea/02_RTC_Conte nt/022_Training/0222_Training_docu ments/02225_USTER/USTER\%20H VI\%20Instruction/0222523_MILL_H VI1000_INSTR_01210.pdf

Braden, C., Smith, C.W., Thaxton, P. \& Hequet, E. (2004). Determining gin variability for HVI and AFIS data. Beltwide Cotton Conferences, San Antonio, 1113. https://www.cotton. org/beltwide/proceedings/2004/abstr acts/G032.cfm

Bradow, J.M. \& Davidonis, G.H. (2000). Quantitation of fiber quality and the cotton production-processing interface: A physiologist's perspective, J. Cotton Sci., 4, 34-64, https://www.cotton.org/journal/200004/1/upload/jcs04-034.pdf

Elms, M.K., Green, C.J. \& Johnson, P.N. (2001). Variability of cotton yield and quality. Comm. Soil Sci. Plant Anal., 32(3-4): 351-368. DOI: 10.1081/css100103012

Green, C.C. \& Culp, T.W. (1990). Simultaneous improvement of yield, fiber quality, and yarn stregth in upland cotton. Crop Sci., 30(1): 66-69, DOI: 10.2135/cropsci1990.00 11183x003000010015x

Gürel, A., Akdemir, H., Emiroğlu, Ş.H., Kadoğlu, H. \& Karadayı, H.B. (2000). Pamuk Tarımı, Teknolojisine
Genel Bakış ve Diğer Lif Bitkileri, TMMOB V. TZM Teknik Kongresi, Ankara, 525-566. https://www.zmo. org.tr/resimler/ekler/28752f77ada1b 8b_ek.pdf?.

Karademir, E., Karademir, Ç., Ekinci, R. \& Sevilmiş, U. (2015). İleri Generasyondaki Pamuk (Gossypium hirsutum L.) Hatlarında Verim ve Lif Kalite Özelliklerinin Belirlenmesi. Türkiye Tarımsal AraştırmalarDergisi, 2(2): 100-107, DOI: 10.19159/tutad. 60964

Kelly, C.M., Osorio-Marin, J., Kothari, N., Hague, S. \& Dever, J.K. (2019). Genetic improvement in cotton fiber elongation can impact yarn quality. Ind. Crops Prod., 129, 1-9, DOI: 10.1016/j.indcrop.2018.11.066

Long, R.L., Bange, M.P., Gordon, S.G., van der Sluijs, M.H.J., Naylor, G.R.S. \& Constable, G.A. (2010). Fiber quality and textile performance of some Australian cotton genotypes. Crop Sci., 50(4): 1509-1518, DOI: 10.2135/cropsci2009.10.0600

Majumdar, A., Majumdar, P.K. \& Sarkar, B. (2005). Determination of the technological value of cotton fiber: A comparative study of the traditional and multiple criteria decision-making approaches. AUTEX Res.J., 5 (2): 71-80. http://www.autexrj.com/cms/ zalaczone_pliki/1-05-2.pdf

Manandhar, R. (2013). Impact of cotton fiber maturity for cotton processing, doctoral thesis, Texas Tech University Department of Plant and Soil Science, Texas, 1-350, https://ttu-ir.tdl.org/bitstream/handle/ 2346/58436/MANANDHAR-DISSER TATION-2013.pdf?sequence $=1$

Mathangadeera, R.W., Hequet, E.F., Kelly, B., Dever, J.K. \& Kelly, C. M. (2020). Importance of cotton fiber elongation in fiber processing. Ind. Crops Prod., 147: 112217, DOI: 10.1016/j.indcrop.2020.112217

Meredith, W.R. Jr. (1986). Fiber quality variation among USA cotton growing regions. Proceeding Beltwide Cotton 


\section{DETERMINATION OF THE FACTORS LIMITING COTTON FIBER QUALITY}

Conference, National Cotton Council, 105-106, https://www.cotton.org/belt wide/proceedings/8395/abstracts/69 9.cfm

Özbek, N. (2013). Türk Pamuklarında Standardizasyonun Gelişimi ve Türk Pamuklarının Durumu, Türkiye Tohumcular Birliği Dergisi, 21: 4750, http://www.upk.org.tr/User_Files/ editor/file/Turk\%20Pamuklarinda\%2 0Standardizasyonun\%20Gelisimi.pdf

Özbek, N., Borzan, G., Kocatürk, H.K., Karademir, Ç. \& Özkan, O.N. (2014). Türkiye Pamuk Lif Kalite Veri Tabanının Oluşturulması, Proje Sonuç Raporu, T.C. Gıda, Tarım ve Hayvancılık Bakanlığı, Tarımsal Araştırmalar ve Politikalar Genel Müdürlüğü Pamuk Araştırma İstasyonu Müdürlüğü, 74, Aydın/ Nazilli, 1-106.

Öztürk, S. (2011). Boyanmış Pamuklu Kumaşlarda Bazı Renk Haslıklarının Değişim Kinetiğinin Renk Ölçümleri ile Araştırılması, Yüksek Lisans Tezi, Uludağ Üniversitesi Fen Bilimleri Enstitüsü Tekstil Mühendisliği Ana Bilim Dalı, Bursa, 1-7.

Reddy, K.R., Davidonis, G.H., Johnson, A.S. \& Vinyard, B.T. (1999). Temperature regime and carbon dioxide enrichment alter cotton boll development and fiber properties. Agron.J., 91(5): 851-858: DOI: 10.2134/agronj1999.915851x

Quisenberry, J.E. \& Kohel, R.J. (1975). Growth and development of fiber and seed in upland cotton. Crop Sci., 15(4): 463-467. DOI: $10.2135 /$ crops ci1975.0011183x001500040005x

Sabır, E.C. \& Güzel, G. (2010). Türkiye'de ve Dünyada Pamuğun Balyalama Standardizasyonu: Genel Bakış ve Son Durum, Ç.Ü.Müh. Mim.Fak.Dergisi, 25(1-2): 135-154, https://dergipark.org.tr/tr/pub/cukuro vaummfd/issue/22768/243019

Siddiqui, M.Q., Wang, H. \& Memon, H. (2020). Cotton science and processing technology. Chapter 6, Cotton Fiber Testing, Hua, Wang,
Memon, Hafeezullah (Eds.) DOI: 10.1007/978-981-15-9169-3.

Silvertooth, J.C. (2001). Crop management for optimum fiber quality and yield, the University of Arizona College of Agriculture and Life Sciences Cooperative Extension,1-2. https://extension. arizona.edu/sites/extension.arizona. edu/files/pubs/az1219-2015.pdf

Snider, J.L., Collins, G D., Whitaker, J. \& Davis, J.W. (2013). Quantifying genotypic and environmental contributions to yield and fiber quality in Georgia: Data from seven commercial cultivars and 33 yield environments. J.Cotton Sci., 17: 285-292, https://www.cotton.org/jour nal/2013-17/4/upload/JCS17-285.pdf

Tümer, H.T. (2010). Çırçırlama Yöntemlerinin Pamuk Kalitesi Üzerine Etkileri, Yüksek Lisans Tezi, Çukurova Üniversitesi Fen Bilimleri Enstitüsü, Adana, 43-44. https://www.ulusaltezmerkezi.net/cir cirlama-yontemlerinin-pamukkalitesi-uzerine-etkileri/24/

Van der Sluijs, M.H. (2015). Impact of the ginning method on fiber quality and textile processing performance of long staple upland cotton. Text.Res.J., 85(15): 1579-1589, DOI: 10.1177/0040517515569524

Wang, Y., Shu, H., Chen, B., McGiffen, M.E., Zhang, W., Xu, N. \& Zhou, Z. (2008). The rate of cellulose increase is highly related to cotton fibre strength and is significantly determined by its genetic background and boll period temperature. Plant Growth Regul., 57(3), DOI: 10.1007/s10725-0089337-9

Wang, X., Zhang, L., Evers, J.B., Mao, L., Wei, S., Pan, X., ... \& Li, Z. (2014). Predicting the effects of environment and management on cotton fibre growth and quality: a functional-structural plant modelling approach. AoB Plants, 6(0): plu040, DOI: 10.1093/aobpla/plu040 